\author{
KRYSTYNA SKWARŁO-SOŃTA
}

\author{
Zakład Fizjologii Zwierzat \\ Wydziat Biologii \\ Uniwersytet Warszawski \\ Miecznikowa 1, 02-096 Warszawa \\ E-mail: kss25@biol.uw.edu.pl
}

\title{
ŚWIATŁO W NOCY: CZY TYLKO ZABURZENIA JAKOŚCI SNU? MECHANIZMY EPIGENETYCZNE POŚREDNICZĄEE WE WPŁYWIE ZANIECZYSZCZENIA ŚWIETLNEGO NA ORGANIZM CZŁOWIEKA
}

\section{WSTEP}

Od kiedy człowiek posiadł zdolność krzesania ognia i idące w ślad za tym źródło światła, sztuczne oświetlenie towarzyszy nam nieodłącznie. Przez wieki zmieniały się jego źródła i dostępność, ale prawdziwy przełom dokonał się w 1879 r., kiedy po raz pierwszy ulice Nowego Jorku oświetliła żarówka elektryczna. Od tego momentu przestały istnieć wszelkie ograniczenia w wykorzystywaniu sztucznego światła, zarówno do rozjaśniania ciemności nocy na zewnątrz, jak i oświetlania pomieszczeń, czego skutkiem czas pracy, życia rodzinnego i społecznego stał się niczym nieograniczony. Wydawać by się więc mogło, że możliwość stosowania sztucznego oświetlenia generuje wyłącznie różnego rodzaju korzyści, od lepszej widzialności i poczucia bezpieczeństwa, przez wydłużenie czasu pracy i większą jej wydajność, aż po nielimitowany czas na rozrywke i życie towarzyskie (GASTON i współaut. 2015). Z czasem zaczęto także doskonalić źródła sztucznego światła, które, od żółto świecącego łuczywa i świecy, przez lampe naftowa i już tylko wspominana stara, dobrą żarówkę sodowa, staje się coraz jaśniejszym zimnym światłem LED (ang. light emiting diode), niezbyt przyjaznym dla użytkowników, ale za to oszczędnie zużywajacym energię elektryczna, a więc pozornie bardziej korzystnym dla środowiska (AUBE i współaut. 2013, SKWARŁO-SOŃTA 2014).
To nieograniczone stosowanie wszechobecnego oświetlenia zaczęło jednak przeszkadzać - najpierw astronomom, którzy stanęli przed problemem coraz trudniejszego znajdowania na całej kuli ziemskiej miejsc dogodnych do instalowania wielkich teleskopów, umożliwiających obserwacje nocnego nieba i prowadzenia badań Kosmosu (KOŁOMAŃSKI 2014, WESOŁOWSKI i GRONKOWSKI 2019). Dało to sygnał do uważniejszego przyjrzenia się temu zjawisku i stosunkowo szybko pojawiło się pierwsze ostrzeżenie NASA mówiące o „ciemnej stronie nadmiaru światła". Tak zrodziło się pojęcie zanieczyszczenia świetlnego lub skażenia światłem (ang. light pollution), oznaczające obecność sztucznego świtała o niewłaściwej porze lub w nadmiernej ilości. Żeby jednak nie stwarzać wrażenia, że rozpoczęła się wojna $z$ elektrycznością czy światłem jako takim wprowadzono uściślenia, dotyczące obecności światła w nocy (ang. light at night, LAN) lub bardziej precyzyjnie, sztucznego swiatła $\mathrm{w}$ nocy (ang. artificial light at night, ALAN). Ten pozornie niewinny skrót będzie używany w niniejszym tekście na określenie wszelkich sytuacji zwiazanych $z$ nadmierna obecnościa sztucznego światła $z$ różnych źródeł i w różnych okolicznościach, często także w takich warunkach, które przeciętnemu użytkownikowi urządzeń elektrycznych, podróżnikowi czy pracownikowi w systemie zmianowym, zupełnie nie kojarza się $z$ zanieczyszczeniem świetlnym. Zwłaszcza, że w obiegowym pojęciu światło odbierane jest raczej pozytyw- 
nie, a pojęcie „zanieczyszczenia świetlnego" do niedawna wywoływało raczej zdziwienie niż konotacje negatywne (ROGE-WIŚNIEWSKA 2014). Dowodem tego były takie właśnie reakcje osób ankietowanych w wywiadach ulicznych, przeprowadzonych przez organizatorów pierwszej Ogólnopolskiej Konferencji na temat Zanieczyszczenia Świetlnego (I OKZŚ), która odbyła się na terenie Wydziału Biologii Uniwersytetu Warszawskiego 23 kwietnia 2013 r. Wtedy po raz pierwszy zaczęto w Polsce głośno mówić o zanieczyszczeniu świetlnym w kontekście badań naukowych, prowadzonych w świecie od dłuższego czasu i $z$ coraz większa intensywnością. Materiały $z$ tej pierwszej konferencji ukazały się drukiem w Wydawnictwie Uniwersytetu Warszawskiego „Prace i Studia Geograficzne”, tom 53, 2014. Konferencja przybrała postać regularnie odbywajacych się spotkań specjalistów z różnych dziedzin życia, i do tej pory odbyło się w kraju pięć OKZŚ (https://ciemneniebo.pl/pl/ogolnopolskie-konferencje-ntzanieczyszczenia-swiatlem/) oraz jedna międzynarodowa (EALPO; http://lightpollution. pk.edu.pl/EALPO_2019/). Pod podanymi adresami dostępne sa materiały informujace o programach poszczególnych konferencji.

\section{ZEGAR BIOLOGICZNY I JEGO ORGANIZACJA U LUDZI}

Mieszkańcy planety Ziemia, od drobnoustrojów po człowieka, pozostaja pod wpływem specyficznych warunków astronomicznych wynikających $z$ jej ruchów. Jest to zarówno obrót wokół własnej osi, generujący dzień i noc, jak i obieg Słońca, którego wynikiem są pory roku, szczególnie dobrze widoczne na naszej półkuli północnej. Towarzyszace temu zjawiska przyrodnicze, takie jak dobowe i sezonowe różnice temperatury, pływy księżycowe czy sezonowe występowanie różnej wilgotności i zmiennej wegetacji roślin, sa efektem nieuchronnie po sobie nastepujacych dni i nocy oraz ich sezonowo zmieniającej się długości. Bez względu zatem na to, czy dzień jest jasny i ciepły czy ciemny i dżdżysty, wiosna słoneczna, a zima bezśnieżna - zawsze jest pewne, że dzień i noc następuja po sobie $z$ niezmienna regularnościa, a pory roku będa się wiąały $z$ kolejnymi zmianami długości dnia i nocy, powtarzającymi się $\mathrm{w}$ cyklu rocznym. $\mathrm{Z}$ osobistego doświadczenia wiemy, że nasz organizm funkcjonuje zupełnie inaczej w jasnej $\mathrm{i}$ ciemnej porze doby, zwłaszcza wówczas, kiedy dzień jest pora wykonywania pracy (czy szerzej rozumianej aktywności życiowej), a noc przeznaczamy na sen. Takie intuicyjne wyczucie podpowiada nam, że w organizmie musi znajdować się „licznik czasu”, który odmierza upływające godziny i "nakazuje” organizmowi zarówno udanie się na spoczynek w godzinach wieczornych, jak i poranna gotowość podejmowania czekających zadań. Zaś w ciagu dnia miewamy okresy większej i mniejszej sprawności umysłowej i fizycznej, pojawia się czasem chęć krótkiej popołudniowej drzemki, a już na pewno mamy temperaturę ciała całkiem naturalnie różna w ciagu doby: niska wcześnie rano, a podwyższoną późnym popołudniem, zaś obserwacja tej reguly pozwala w najprostszy sposób ocenić stan zdrowia.

Czynnikiem „dyktujacym” te wszystkie regularnie powracające różnice w przebiegu procesów i zachowaniu (nie tylko człowieka, ale także zwierząt i roślin) jest mechanizm molekularny, odmierzajacy upływ czasu i pozwalajacy przewidywać następstwo zdarzeń. Domyślamy się także, iż ten endogenny, a więc pochodzacy $z$ samego organizmu, mechanizm musi być $\mathrm{w}$ jakiś sposób skomunikowany $z$ otoczeniem, od którego odbiera ważne sygnały, informujace o aktualnej sytuacji w środowisku zewnętrznym. Mechanizmem tym jest zegar biologiczny, czyli struktura zdolna zarówno generować własne „polecenia”, charakterystyczne dla poszczególnych odcinków czasowych doby, jak i odbierajaca informacje środowiskowe, do których dostosowuje swoja aktywność. Ta $z$ kolei przekłada się następnie na funkcjonowanie poszczególnych narząów i całego organizmu. Ten wewnętrzny licznik czasu, czyli zegar biologiczny, przygotowuje organizmy do następujacych $z$ wielka regularnościa zmian w otaczajacym nas świecie

Funkcjonowanie zegara biologicznego jest przedmiotem intensywnych badań, m.in. biologów molekularnych, poszukujących sposobu wyjaśnienia mechanizmów leżących u podstaw możliwości nie tylko endogennego odmierzania czasu, ale także odbierania informacji środowiskowych i kontrolowania czynności życiowych. Wprawdzie chronobiologia, czyli dziedzina biologii zajmujaca się wyjaśnianiem tajników czasowego uporząkowania przebiegu procesów całego świata ożywionego, jest nauka stosunkowo młoda (nie osiagnęła jeszcze pełnego stulecia), ale dzięki dynamicznemu rozwojowi technik molekularnych wiemy już stosunkowo wiele o organizacji i funkcjonowaniu zegara biologicznego. Wiedza ta osiagnęła taki poziom, że doczekała się w 2017 r. nagrody Nobla w dziedzinie medycyny lub fizjologii, która odebrali zajmujacy się chronobiologia molekularna amerykańscy uczeni: Jeffrey C. Hall, Michael Rosbash i Michael W. Young. Przyznajacy nagrodę komitet $z$ Karolinska Institutet argumentował, że laureaci swoimi badaniami „Zwiększyli świadomość znaczenia 


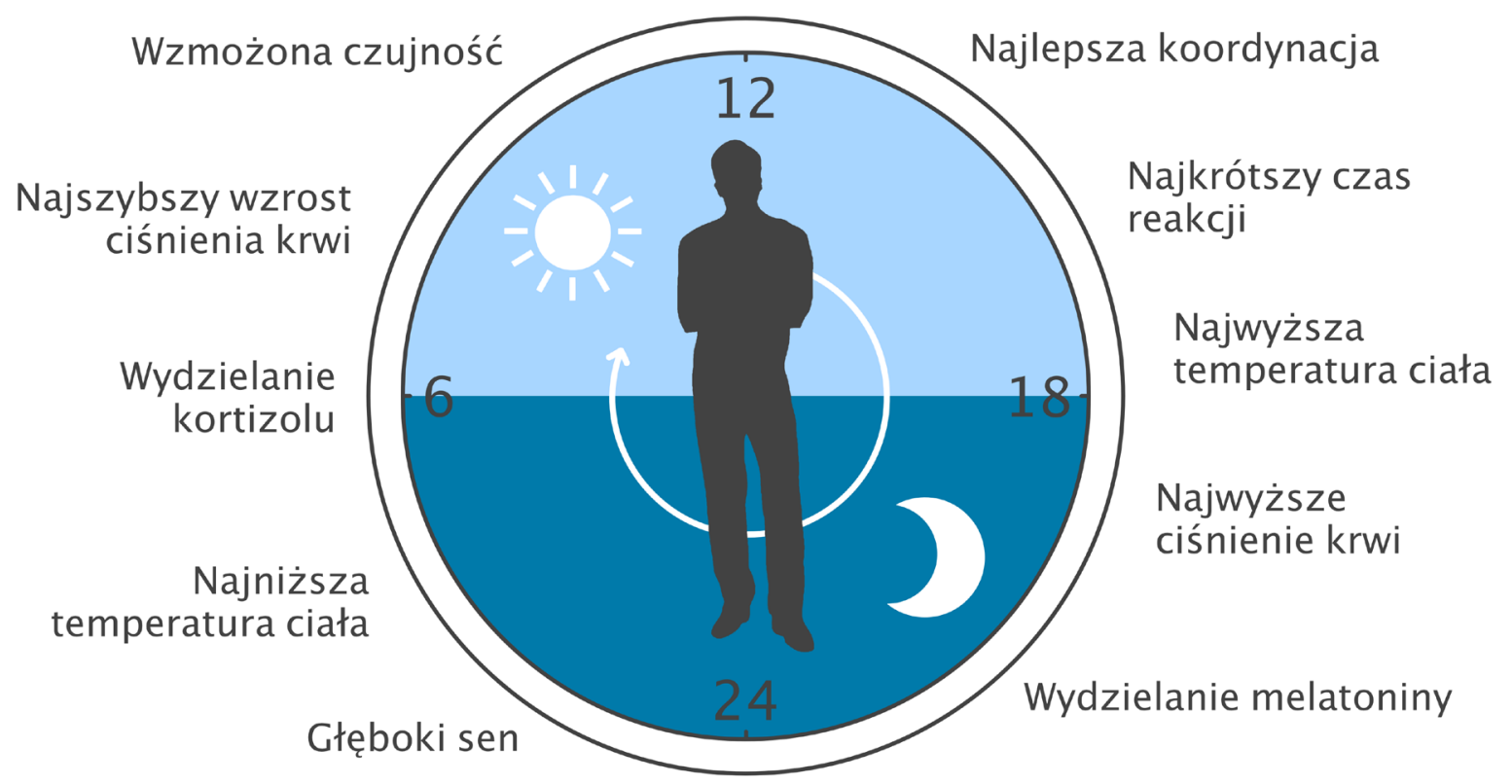

Ryc. 1. Dobowy rozkład wybranych czynności życiowych człowieka - na podstawie strony internetowej Komitetu Noblowskiego 2017.

właściwej higieny snu" (https://www.nobelprize.org/prizes/medicine/2017/summary/). Jest to szczególnie istotne w świetle faktu, że wyróżnieni naukowcy swoje badania prowadza na modelowym organizmie Drosophila melanogaster, czyli powszechnie znanej, i dość ucią̇liwej na co dzień, „muszce owocowej" (wywilżna). Oznacza to bowiem, że zegar molekularny jest mechanizmem uniwersalnym, który, $z$ niewielkimi różnicami u poszczególnych gatunków, funkcjonuje w całym świecie ożywionym, a już na pewno w królestwie zwierzat. Więcej informacji na temat zegara molekularnego znajda czytelnicy w innych artykułach tego tomu, polecam też dostępne opracowania przeglądowe (np. BELL-PEDERSEN i współaut. 2005, FOSTER i KREITZMAN 2014, GIEBULTOWICZ 2018). Badany przez noblistów 2017 r. mechanizm molekularny zegara biologicznego pozwala zaadaptować nasza fizjologię do różnych faz dnia oraz zsynchronizować procesy $\dot{z} y-$ ciowe organizmów $z$ cyklicznymi zmianami zewnętrznych warunków środowiska (oświetlenia), co ilustruje schemat, zaczerpnięty ze strony internetowej Komitetu Noblowskiego 2017 (Ryc. 1).

Zegar biologiczny człowieka i innych ssaków, to zespół struktur generujących rytmiczny przebieg poszczególnych procesów zachodzacych w organizmie. Rytmy te nazywamy okołodobowymi (cirkadialnymi; łac. circa - około i dies - dzień), ponieważ procesy powtarzaja się $z$ regularnościa bliska 24-godzinnej dobie, niekiedy trwając trochę dłużej lub krócej. Zegar ma strukturę hierarchiczna, na szczycie której znajduje się zegar (oscylator) centralny (ang. master clock), utworzony przez parzyste skupiska neuronów, tzw. jądra nadskrzyżowaniowe (łac. suprachiasmatici nuclei, SCN), zlokalizowane w podwzgórzu w bliskości trzeciej komory mózgu. Cecha centralnego zegara jest spontaniczne generowanie zmiennej w ciagu doby aktywności elektrycznej neuronów, wysokiej w dzień i niskiej w nocy, przekładającej się na rytmiczna syntezę i sekrecję neuroprzekaźników, będących tzw. droga wyjścia $z$ zegara. Oznacza to, że przy pomocy mechanizmów neurohormonalnych SCN sprawuje kontrolę nad zachowaniem i wszystkimi czynnościami życiowymi człowieka (zwierzęcia) (BELL-PEDERSEN i współaut. 2005). Najsilniej wyrażonymi rytmami dobowymi kontrolowanymi przez SCN jest sen i czuwanie (aktywność ruchowa) oraz wspomniana już temperatura ciała, a także rytmy dobowe wydzielania niektórych hormonów. Przykładem może być maksymalne stężenie glukokortykoidów w krwi występujace podczas przechodzenia od okresu snu do pełnej aktywności ruchowej (początek dnia u ludzi i zwierząt o aktywności dziennej a początek okresu ciemności u gryzoni laboratoryjnych) czy nocny szczyt wydzielania hormonu wzrostu. Odrębna pozycję zajmuje tu nocna synteza i wydzielanie melatoniny szyszynkowej, czyli hormonu ciemności (SKWARŁO-SOŃTA 2014), co będzie szerzej omówione w dalszej części tekstu.

Zegar centralny nie jest jedyna struktura zaangażowana w uporządkowanie w czasie przebiegu procesów zachodzących w organizmie. Pod jego kontrolą znajdują się tzw. ze- 
gary obwodowe (peryferyczne), których obecność wykryto prawie wszędzie, a zwłaszcza w narzadach zwiazanych $\mathrm{z}$ układem pokarmowym (wątroba, tkanka tłuszczowa, gruczoły trawienne). Ich mechanizm molekularny jest taki sam jak zegara nadrzędnego, a funkcja polega na sprawowaniu kontroli nad przebiegiem procesów metabolicznych (FROY 2011), których zakłócenie skutkuje różnego rodzaju zaburzeniami, w tym cukrzyca i zespołem metabolicznym, a także chorobami nowotworowymi czy depresja.

\section{DAWCY CZASU DLA ZEGARA BIOLOGICZNEGO}

Synchronizacja zegara $z$ warunkami zewnętrznymi, skutkujaca prawidłowym funkcjonowaniem organizmu, odbywa się za pośrednictwem czytelnych sygnałów środowiskowych zwanych dawcami czasu. W chronobiologii często określa się je zaczerpniętym z języka niemieckiego terminem Zeitgeber, wprowadzonym na cześć jednego $z$ ojców chronobiologii, niemieckiego uczonego Jürgena Aschoffa (1913-1998), który stworzył podwaliny eksperymentalnego poznawania tajników funkcjonowania zegara biologicznego. Dla centralnego zegara w SCN głównym dawca czasu jest światło odbierane przez siatkówkę oka, skąd impulsy nerwowe sa kierowane na pozawzrokowa droge nerwowa, prowadzaca do SCN. Jest to szlak siatkówkowo-podwzgórzowy (RHT), biorący swój początek w tzw. komórkach zwojowych, specjalnej grupie fotoreceptorów siatkówkowych, innych niż zwiazane $z$ widzeniem czopki $i$ pręciki. Komórki zwojowe zawieraja barwnik melanopsynę (BERSON i współaut. 2002), szczególnie wrażliwa na światło niebieskie (460-480 nm). Wygenerowana $\mathrm{w}$ nich informacja o obecności światła zmierza szlakiem RHT do zegara centralnego w SCN, który $\mathrm{w}$ ten sposób jest informowany o obecności (lub braku światła) w środowisku zewnętrznym.

Stad informacja kierowana jest na wieloneuronalny szlak nerwowy, którego zazwojowe włókna współczulne docieraja do szyszynki, gruczołu neuroendokrynowego, kluczowego $\mathrm{w}$ procesie synchronizacji zegara centralnego $z$ zewnętrznymi warunkami świetlnymi (Ryc. 2).

W gruczole tym jest syntetyzowana i natychmiast wydzielana do krwi melatonina, funkcjonujacca u wszystkich kręgowców jako hormon ciemności, bowiem światło, zwłaszcza niebieskie, hamuje jej syntezę. Zagadnienia związane $z$ synteza melatoniny szyszynkowej, jej regulacją i metabolizmem opisałam szczegółowo w pracy przeglądowej opublikowanej przed paru laty w Kosmosie

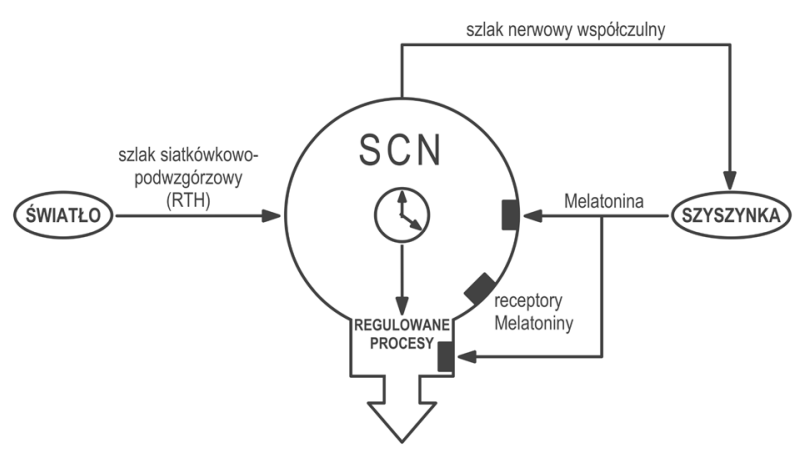

Ryc. 2 Powiąania funkcjonalne między SCN a szyszynką i melatoniną - szczegóły w tekście.

(SKWARŁO-SOŃTA 2014). Tutaj pragnę jedynie zwrócić uwagę, że niczym niezakłócona nocna synteza melatoniny ma podstawowe znaczenie dla synchronizacji zegara centralnego, a co za tym idzie, prawidłowej okołodobowej organizacji przebiegu procesów fizjologicznych w organizmie, a zwłaszcza snu i czuwania. Błonowe receptory melatoniny, należace do rodziny receptorów związanych z białkami G (GPCR), zlokalizowane sa nie tylko w neuronach SCN, ale występuja także w wielu strukturach ośrodkowego układu nerwowego oraz w tkankach obwodowych, przejmujac od melatoniny informacje o panujacej ciemności. Brak lub niski poziom melatoniny w krwi jest odbierany jako dzień, dlatego melatonina pełni $\mathrm{w}$ organizmie rolę zegara i kalendarza - po bardziej szczegółowe informacje odsyłam do kliku przykładowych prac przegladowych (REITER 1993, DUBOCOVICH i MARKOWSKA 2005, SKWAREO-SOŃTA i MAJEWSKI 2010).

Efekty fizjologiczne melatoniny w mózgu związane sa $\mathrm{z}$ aktywowaniem jej GPCR podzielonych u ssaków na dwa podtypy: MT1 i MT2. Obydwa podtypy receptorów uruchamiaja ten sam mechanizm transdukcji sygnału: hamowanie cyklazy adenylanowej, skutkiem czego następuje spadek wewnatrzkomórkowego cAMP. Receptory te tworza heterodimery MT1/MT2, a nawet dimeryzuja $z$ innymi receptorami, np. $z$ receptorem serotoniny 5-HT2c, i takie oligomery wykazuja odmienne od homomerów właściwości funkcjonalne. Najnowsze badania $z$ udziałem mutantów i myszy knock-out wykazały przeciwstawne efekty wywołane po aktywacji obu podtypów receptorów melatoniny $\mathrm{w}$ odniesieniu do poszczególnych faz snu: MT1 pośredniczą głównie $\mathrm{w}$ regulacji fazy snu REM, natomiast MT2 selektywnie zwiększaja czas trwania fazy NREM (GOBBI i COMAI 2019). Podobnie selektywnie sa rozmieszczone obydwa typy receptorów melatoniny w ośrodkach mózgu zwiazanych $z$ fazami snu. 
Te obserwacje tłumaczą przeciwstawne efekty wywoływane przez nieselektywnych agonistów (lub nawet samą melatoninę), stosowanych w badaniach klinicznych jako środki nasenne. Ponadto, receptory MT1 (ale nie MT2) najprawdopodobniej pośrednicza w regulacji rytmu dobowego snu i czuwania, toteż selektywni agoniści tych receptorów powinni być brani pod uwagę w badaniach nad lekami o potencjale psychoneuro-farmakologicznym.

Jak to już wcześniej powiedziano, warunki świetlne otoczenia sa podstawowym dawca czasu dla zegara centralnego „wydajacego swoje polecenia" także dla zegarów obwodowych, do których informacja świetlna nie dociera bezpośrednio. Maja one jednak również własnych dawców czasu, którymi sa przede wszystkim sygnały zwiazane $z$ pokarmem, jego obecnościa i składem, i ta informacja jest tylko pośrednio związana $z$ obecnością światła (GILLMAN i współaut. 2019). Zegary obwodowe uruchamiaja np. mechanizm antycypacyjny, który u zwierząt laboratoryjnych przejawia się wzmożona aktywnościa ruchowa w poszukiwaniu pokarmu, natomiast u ludzi może dotyczyć nienaturalnych pór posiłków, towarzyszących zaburzonym okresom światła i ciemności (patrz część „Zaburzenia zegara biologicznego spowodowane skażeniem światłem”).

\section{SEN I JEGO ZWIAZEK Z ZEGAREM BIOLOGICZNYM}

Sen jest występującym u wszystkich organizmów szczególnym stanem czynnościowym, którego rola i znaczenie fizjologiczne sa ciagle przedmiotem debaty naukowej, choć $z$ cała pewnościa zapadanie w sen jest imperatywem adaptacyjnym. Poszczególne gatunki kręgowców wykazują zróżnicowane zapotrzebowania na ilość snu w ciagu doby (z reguły mniejsze zwierzęta śpią dłużej), nigdy jednak czas przeznaczony na sen nie jest krótszy niż 10\% doby (Ryc. 3). Funkcje snu sa także liczne; przypuszcza się, że sen wiąze się $z$ oszczędzeniem energii i korzystnym jej zagospodarowaniem, czasowym uporządkowaniem metabolizmu i wreszcie wspieraniem wyższych czynności mózgu, takich jak kreatywność, plastyczność synaps, konsolidacja pamięci (ACHERMANN i TAROKH 2014).

Podstawowy model regulacji snu człowieka, zaproponowany przez Borbélyego w 1982 r. (patrz Fig. $3 \mathrm{w}$ pracy ACHERMANN i TAROKH 2014), obejmuje dwie uzupełniające się składowe: proces okołodobowy (C) i homeostatyczny (S). Proces okołodobowy jest generowany przez zegar endogenny, nie zależy od wcześniejszej aktywności ruchowej, trwa około 24 godz. i wyznacza czuwanie w ciagu dnia $\mathrm{i}$ sen $\mathrm{w}$ nocy. Natomiast składowa homeostatyczna oznacza narastająca potrzebę snu podczas okresu aktywności, którą zaspokoić może jedynie zaśnięcie; po zakończonym okresie snu potrzeba kolejnej jego porcji znowu zaczyna progresywnie narastać. Harmonijne współdziałanie obydwu składowych zapewnia dobry sen $\mathrm{w}$ nocy i maksymalna sprawność w ciągu dnia. Jeśli $z$ jakiegoś powodu nie nastapi sen $\mathrm{w}$ zwykłej porze, wówczas potrzeba snu narasta i utrzymuje się tak długo, dopóki nie nastapi kolejna faza snu, która powinna być bardziej regenerująca. Związek melatoniny, jako hormonu ciemności, ze snem u ludzi polega na ułatwianiu zasypiania, a szczyt jej nocnego wydzielania zbiega się $\mathrm{w}$ czasie $\mathrm{z}$ najniższa temperatura ciała i obniżeniem tempa metabolizmu (WichNiaK i współaut. 2017).

Odstępstwa od opisanej regularności okresów snu i czuwania, zwiąane m.in. z desynchronizacja zegara biologicznego spowodowaną różnymi czynnikami, skutkuja wieloma zaburzeniami funkcji organizmu, do których należa problemy $z$ właściwa regulacja metabolizmu. Prowadza one do otyłości na skutek rozregulowania neuroendokrynowej kontroli pobierania pokarmu: obniżone wydzielanie leptyny, czyli hormonu sytości, przy zwiększonym wydzielaniu wzmagajaccej apetyt greliny (KNUTSON i VAN CAUTER 2008), a także do cukrzycy typu 2 (DMT2) i zespołu metabolicznego (przegląd np. w REUTRAKUL i VAN CAUTER 2014).

Przykładem sytuacji prowadzącej do desynchronizacji rytmu dobowego snu i czuwania jest nocna praca zmianowa, podczas której pracownicy pozostają aktywni i pobieraja pokarm w nocy, czyli w okresie zwyczajnie przeznaczonym na sen, natomiast sen i wstrzymywanie się od jedzenia prze-

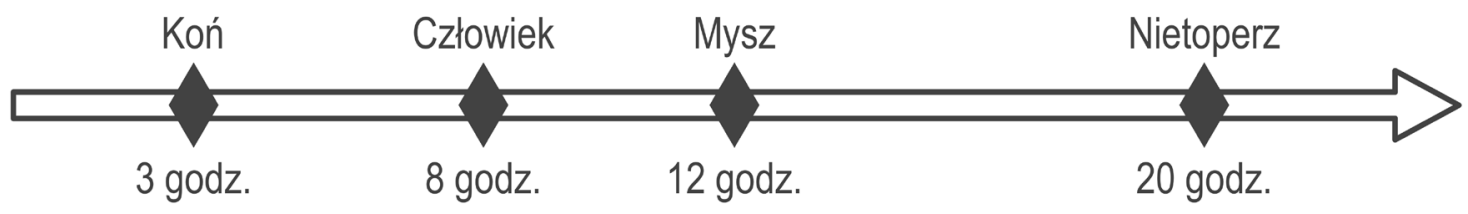

Ryc. 3. Czas snu niektórych gatunków ssaków w ciagu doby (wg BRINGMANN 2019). 
noszą na dzień (fazę jasną). Liczne badania populacyjne dowodziły, że osoby pracujace przez kilkanaście lat w systemie nocnej pracy zmianowej (najczęściej pielęgniarki) wykazują zwiększone ryzyko rozwoju otyłości i DMT2, proporcjonalnie do czasu trwania tej formy zatrudnienia. Również w kontrolowanych warunkach doświadczalnych stwierdzono, że u osób $z$ nienaturalnymi porami snu i posiłków następuje wzrost spoczynkowego i poposiłkowego poziomu glukozy, zaburzenia wydzielania leptyny oraz funkcji komórek beta trzustki, będacych źródłem insuliny (REUTRAKUl i VAN CAUTER 2014).

\section{WPŁYW SKAŻENIA ŚWIATŁEM NA PROCESY BIOLOGICZNE W PRZYRODZIE}

Odwołując się do definicji skażenia światłem przypominam, że termin ten oznacza obecność światła w niewłaściwej porze i/ lub w nadmiernych ilościach. Za niewłaściwa porę musimy uznać nie tylko zewnętrzne światło $\mathrm{w}$ nocy, pochodzące $\mathrm{z}$ oświetlanych ulic, placów i parkingów, gmachów zabytkowych lub ważnych budowli użyteczności publicznej, mostów, kościołów, oświetlonych samochodów czy wręcz światło saczace się $\mathrm{z}$ wnętrz domów i mieszkań, ale także sztuczne światło używane wewnątrz zakładów pracy $\mathrm{w}$ ciagu dnia. W krajach rozwiniętych sztuczne światło stosowane w dzień jest stosunkowo słabe (jako normę wystarczajaca do wykonywania potocznych czynności przyjęto 500 lux), dlatego mieszkańcy dużych miast europejskich rzadko $\mathrm{w}$ ciagu dnia maja do czynienia $z$ naturalnym światłem słonecznym, którego intensywność „w plenerze" może w jasne letnie dni osiagać wartości setek tysięcy lux. Natomiast bardzo często doświadczaja w nocy światła o jasności przekraczajacej światłość pełni księżyca (BONMATI-CARRION i współaut. 2014). Taka niewielka dzienno-nocna różnica $\mathrm{w}$ intensywności oświetlenia sprawia, że sygnał świetlny staje się słabym dawca czasu dla zegara biologicznego, który zaczyna wówczas wykazywać symptomy desynchronizacji (RoENNEBERG i współaut. 2019).

Obecnie na oświetlenie w niewłaściwych ilościach i porach narażeni sa przede wszystkim mieszkańcy dużych miast, w których światła uliczne po prostu „zagladaja ludziom w okna" także w nocy i często nie można się od nich uwolnić. A nawet ta niewielka ilość światła $\mathrm{w}$ nocy nie pozostaje bez wpływu na funkcjonowanie organizmu człowieka, czego dowodem sa wyniki wieloletnich badań ankietowych, przeprowadzonych w Wielkiej Brytanii na ogromnej grupie ponad 100 tysięcy kobiet $\mathrm{w}$ przedziale wiekowym od 16 do 103 lat (śr. 47,2 lata). Kobiety były pytane o jasność pokoju, w którym sypiaja, określały też własną masę ciała i inne wskaźniki socjo-fizjologiczne, co pozwoliło na przeprowadzenie analiz korelacyjnych. Okazało się, że sypianie w pomieszczeniu, którego jasność pozwalała na czytanie lub rozróżnianie przedmiotów, skutkowało nadwaga lub otyłościa i była to korelacja wysoce istotna statystycznie - po uwzględnieniu wszelkich innych cech indywidulanych mogacych mieć wplyw na stwierdzone zależności (MCFADDEN i współaut. 2014). Jeśli pokój był słabiej oświetlony (możność widzenia lub niewidzenie własnych dłoni) taka zależność nie występowała. Badania te zostały skomentowane $\mathrm{w}$ tym samym numerze czasopisma $\mathrm{w}$ komplementarnym artykule (GANGWISCH 2014), którego autor analizuje wage obserwacji poczynionych na tak dużej populacji o znacznej rozpiętości wiekowej, podkreślając negatywną rolę postępu technicznego, wymagającego nielimitowanej ilościowo i w czasie ekspozycji na sztuczne światło, co pociaga za sobą różne pory posiłków i aktywności fizycznej w ciagu doby. $\mathrm{Sa}$ to czynniki zaburzajace naturalny rytm dobowy i sezonowy podstawowych funkcji życiowych człowieka, których ograniczenie powinno być brane pod uwage w kontekście podejmowania prób zmniejszenia powszechności chorób tzw. cywilizacyjnych.

Życie w warunkach nadmiernych i/ lub niewłaściwie używanych ilości światła sztucznego jest poważnym utrudnieniem dla całego ekosystemu. Oprócz człowieka, cierpią $z$ tego powodu również zwierzęta, rośliny, a także zaburzone zostaja relacje rośliny-zapylacze, co stanowi poważne zagrożenie dla ciagłości łańcucha pokarmowego, bowiem co najmniej 30\% spożywanego przez nas pożywienia jest efektem zapylania roślin przez zwierzęta. Te pasjonujące zagadnienia wykraczaja jednak poza ramy tego opracowania, a zainteresowanych odsyłam do łatwo dostępnych polskojęzycznych artykułów (zwierzęta: WOJCIECHOWSKA i współaut. 2014; rośliny: WoJCIECHOWSKA 2019; relacje rośliny-zapylacze: ZYCH i RYNIEWICZ 2019).

\section{ZABURZENIA ZEGARA BIOLOGICZNEGO SPOWODOWANE SKAŻENIEM SWWIATŁEM}

Jednym ze źródeł skażenia światłem zaburzajacym funkcjonowanie zegara biologicznego ludzi sa sytuacje życiowe, wymuszające pozostawanie pod wpływem sztucznego oświetlenia również $\mathrm{w}$ nocy, a więc $\mathrm{w}$ porach naturalnie przeznaczonych na sen. Sa to podróże transkontynentalne, wspomniana już praca zmianowa oraz korzystanie (dobro- 
wolne lub wymuszone np. warunkami pracy) $z$ urządzeń elektronicznych emitujacych światło, zwłaszcza niebieskie światło LED (na które szczególnie wrażliwe sa receptory melanopsynowe siatkówki), czyli wszechobecne smartfony, laptopy, e-booki, a nawet ekrany odbiorników TV, bardzo często używane w sypialniach i towarzyszace ludziom podczas snu. Wspólna cecha tych urządzeń i sytuacji życiowych jest oddziaływanie światła noca na szyszynkę, hamujace syntezę melatoniny, przez co zaburzone zostaje funkcjonowanie całego systemu zegarowego człowieka.

Kilkugodzinne czytanie e-booka przez 5 kolejnych wieczorów, w porównaniu ze skutkami tak samo zaplanowanego czytania drukowanej ksiażki (przez te same osoby), wywierało bardzo wyraźny wpływ na funkcjonowanie zegara, szyszynki, jakość snu i zdolność koncentracji następnego dnia (CHANG i współaut. 2015). Czytanie ksiażki na nośniku elektronicznym obniżało poziom melatoniny o ok. 50\%, a poczatek syntezy melatoniny (miara jego jest wskaźnik DLMO, czyli Dim Light Melatonin Onset) był opóźniony o prawie 1,5 godz. w stosunku do sytuacji, kiedy te same osoby czytały książke drukowaną. Nie uległ zmianie ogólny czas trwania snu ani średni czas poszczególnych jego faz, natomiast zaobserwowano istotne wydłużenie średniej latencji snu N2 (faza druga snu NREM), przy skróceniu średniej skumulowanej ilości snu REM podczas 8-godzinnego snu. Podczas czytania książki elektronicznej zaobserwowano obniżona senność, mniej mózgowych fal delta/teta, natomiast te same osoby budziły się rano $z$ większym uczuciem senności i potrzebowały więcej czasu do osiąnniecia czujności porównywalnej $z$ sytuacją po czytaniu książki tradycyjnej. Ponieważ podczas czytania obydwu typów książek istotną różnicę stanowiła wyłącznie długość fali światła padajacego na siatkówkę (450 $\mathrm{nm}$ z e-booka vs $620 \mathrm{~nm}$ odbite od ksiązki drukowanej) należy uznać, że to właśnie jakość światła jest przyczyna tak poważnych konsekwencji w parametrach fizjologicznych uczestników tego badania. Opóźniony rytm dobowy syntezy melatoniny pociaga za soba opóźnioną senność wieczorna, niedobory snu i jego gorsza jakość oraz gorsze samopoczucie nazajutrz (CHANG i współaut. 2015). Hamowanie syntezy melatoniny pod wpływem światła emitowanego przez urządzenia elektroniczne wykazano również u osób korzystajacych $z$ komputerów w godzinach nocnych (WoOD i współaut. 2012). Przebywanie przed ekranem emitujacym niebieskie światło przez 1-2 godz. powodowało zmniejszenie syntezy melatoniny nawet o ok. $70 \%$, czego nie obserwowano, jeśli ekran był tej emisji pozbawiony. Obydwa badania wskazują, że źródłem zaburzeń jest zmniejszona synteza melatoniny pod wpływem niebieskiego światła działajacego w nocy na siatkówkę oka ludzkiego i dotyczy to nie tylko użytkowników urządzeń elektronicznych. Obecność ALAN wpływa na organizm w dwojaki sposób: efekt ostry wynika $z$ hamowania syntezy melatoniny szyszynkowej, zaś działanie ogólnoustrojowe jest skutkiem desynchronizacji funkcjonowania zegara endogennego.

Uzupełnieniem tych danych eksperymentalnych sa wyniki najnowszych badań zaburzeń snu, przeprowadzonych w Chinach podczas aktualnej epidemii COVID-19 (ZHANG i współaut. 2020). Spośród ankietowanych 1563 pracowników medycznych, zaangażowanych w leczenie pacjentów w najgorętszej fazie epidemii koronawirusa, 564 osoby $(36,1 \%)$ wykazywały oznaki bezsenności, diagnozowanej na podstawie 8-stopniowej skali Insomnia Severity Index (ISI). Skala problemu była porównywalna $z$ wynikami pomiarów wykonanych kilka lat wcześniej podczas epidemii SARS w Hong Kongu i na Taiwanie. Bezsenności towarzyszyła często depresja, związana $z$ licznymi czynnikami psycho-socjologicznymi, głównie stresem zwiazanym $z$ poczuciem braku właściwego zabepieczenia przed infekcja, niepokojem o zdrowie własne i rodziny, izolacja społeczna itp. Jednak część problemów ze snem mogła wynikać $z$ zaburzeń rytmu dobowego, byli to bowiem pracownicy pierwszego kontaktu $Z$ chorymi, działajacy $\mathrm{w}$ systemie zmianowym, często bez czasowych przerw na odzyskanie normalnego cyklu snu i czuwania. Co ciekawe i zastanawiajace dla autorów opracowania, lekarze w porównaniu do pielęgniarek rzadziej deklarowali tego rodzaju problemy: bezsenność, niedobory snu i senność podczas dnia, co nie koniecznie musi się wiąać z wyższym wykształceniem (doktoraty lekarzy us szkoła średnia pielęgniarek). Odpowiedzialny za te zaburzenia jest niewatpliwie przede wszystkim dobowy rozkład obowiazków, bowiem lekarze zajmowali się pacjentami głównie w ciagu dnia, natomiast pielęgniarki pozostawały na nocnych dyżurach sprawujac całodobowa opieke nad pacjentami, co jest znanym czynnikiem desynchronizującym zegar biologiczny (ZHANG i współaut. 2020).

Doceniając wage i zakres problemu Międzynarodowa Agencja ds. Badań nad Rakiem (IARC) uznała nocna pracę zmianowa, a więc przebywanie pod wpływem światła w godzinach nocnych, za czynnik ryzyka rozwoju raka piersi (IARC 2010) - do tego zagadnienia powrócimy w dalszej części tekstu.

Jest też jednak pewna nadzieja na możliwość przywrócenia normalnej funkcji zegara 
biologicznego dzięki powrotowi do naturalnego rozkładu okresów światła i ciemności w ciagu doby, powodującego re-synchronizację cyklu snu i czuwania oraz regularnej pory DLMO i końca nocnej syntezy melatoniny. Wskazuja na to wyniki badania terenowego przeprowadzonego wprawdzie na niewielkiej grupie ośmiu ochotników (WRIGHT i wspó1aut. 2013), których wskaźniki pracy zegara endogennego oraz wielkość ekspozycji na swiatło szacowano w warunkach wielkiego miasta (Denver, Colorado, USA) i po tygodniowym pobycie w Górach Skalistych, bez innych niż naturalne źródeł światła (było to w lipcu a więc w okresie najdłuższych dni). Okazało się, że istotnie ilość światła, $z$ jaka mieszkańcy miasta stykali się w ciagu dnia, jest znacznie niższa niż w naturze (o czym już była mowa uprzednio), ale nie ma te $\dot{z}$ prawdziwie ciemnej nocy w mieście. U takich osób nie ma także wyraźnie zaznaczonej pory nocnego szczytu wydzielania melatoniny, a poczatek snu jest przesunięty na późne godziny nocne. Wszystkie te wskaźniki ulegały pełnej synchronizacji $z$ naturalnym dniem i nocą już po tygodniu pobytu w warunkach kontaktu $z$ wyraźnymi dawcami czasu w postaci jasnego dnia i ciemnej nocy. Wskazuje to także na odwracalność zaburzeń zegara biologicznego, co potwierdzaja badania nad mechanizmami epigenetycznymi pośredniczacymi w desynchronizacji rytmu dobowego pod wpływem skażenia światłem, co będzie szerzej rozwinięte w dalszej części tekstu. Badanie to także rodzi nadzieję na to, że ewolucyjnie utrwalone mechanizmy molekularne naszego zegara biologicznego sa w stanie oprzeć się destrukcyjnym działaniom współczesnego stylu życia (zwanego 24/7/365) zwłaszcza mieszkańców wielkich miast, a wprowadzanie warunków „chronobiologicznie przyjaznych", takich jak unikanie skażenia światłem wszelkiego pochodzenia, pozwoli zachować prawidłowo zsynchronizowane rytmy dobowe, wyrażajace się m.in. właściwymi porami snu i jego dobra jakością (WICHNIAK i współaut. 2017).

\section{UDZIAE MODYFIKACJI EPIGENETYCZNYCH W DESYNCHRONIZACJI RYTMÓW DOBOWYCH POD WPEYWEM ALAN}

Najnowsze badania mechanizmów pośredniczacych we wpływie ALAN na organizmy zwrócily uwage na procesy epigenetyczne, czyli mechanizmy odwracalnie modyfikujące funkcję genów, bez wywoływania zmian w sekwencji DNA. Mechanizmy epigenetyczne obejmuja metylacje DNA, modyfikacje histonów, pozycjonowanie nukleosomów i modyfikacje mikroRNA (GLAVAŠKI i
STANKov 2019). Spośród tych mechanizmów najczęściej badanymi w kontekście zaburzeń zegara biologicznego sa metylacja DNA oraz modyfikacje histonów, i właśnie te mechanizmy zostana tutaj po krótce przedstawione. Osoby szczególnie zainteresowane tymi zagadnieniami odsyłam do bogatej literatury przedmiotu (np. ZHANG i HO 2011, HARDELAND 2017).

Metylacja DNA polega na dodawaniu grup metylowych do sekwencji CpG (tzw. wyspy CpG, czyli dinukleotydy cytozyna-guanina przedzielone liniowo jedna resztą fosforanowa w kierunku 5' - >3'), występujacych $\mathrm{w}$ genomie ssaków szczególnie często w regionach promotorowych. Intensywna metylacja wysp CpG jest charakterystyczna dla genów o wyciszonej ekspresji (JABBARI i BERNARDI 2004). Wykazano, że w nowotworach wyłaczenie ekspresji genów w wyniku hipermetylacji promotorowych wysp CpG niektórych genów ma miejsce 10 razy częściej niż wywołuja to mutacje (HASHIMOTO i współaut. 2010).

Z kolei histony sa białkami zaangażowanymi w upakowanie DNA w nukleosomy tworzace chromatynę. Pojedyncze nukleosomy połaczone krótkimi odcinkami DNA składaja się $z$ oktameru histonowego (po dwie podjednostki H2A, H2B, H3 i H4), na który nawinięty jest łańcuch DNA o długości ok. 146 par zasad. N-końcowe odcinki łańcucha peptydowego histonów sa szczególnie podatne na modyfikacje potranslacyjne, $z$ których najczęstsze to acetylacja i metylacja lizyny (K). W ich wyniku ulega zmianie dostępność transkrypcyjna chromatyny; przyjmuje się, że w histonie 3 trimetylacja lizyny 9 i 27 (H3K9me3 i H3K27me3) sa zwiazane $z$ represja chromatyny, natomiast metylacja lizyny 4 (H3K4me3) czyni chromatynę bardziej dostępna do transkrypcji (FABRIZIO i współaut. 2019). Ostateczny poziom ekspresji poszczególnych genów, będący rezultatem aktywacji lub wyciszania odpowiednich odcinków genomu, jest konsekwencja kombinacji powiazanych ze sobą procesów metylacji DNA i potranslacyjnej modyfikacji histonów.

Modyfikacje epigenetyczne ekspresji genów zegara biologicznego sa badane intensywnie (przegląd w AHMAD i współaut. 2019), mimo to raczej nieliczne sa doniesienia łaczace epigenetyke $z$ desynchronizacja rytmów okołodobowych pod wpływem ALAN. Prace zespołu GRYGORYEVA i współaut. (2018) wykazały, że 6-godzinne przyspieszenie fazy świetlnej $\mathrm{w}$ hodowli myszy trzymanych w warunkach 12-godzinnego światła (L:D 12:12) wpłynęło zarówno na wzrost poziomu, jak i na przyspieszenie fazy rytmu H3K4me3 w promotorach głównych genów zegarowych (Per1, Per2, Cry1, Cry2, 
Bmal1 i Clock) w wątrobie. Rytm dobowy H3K4me3 u myszy kontrolnych pokrywał się z rytmem aktywności lokomotorycznej, czyli był niski podczas dnia, a osiagal szczyt w ciemności. Po zastosowaniu 6-godzinnego światła w nocy następowała początkowa desynchronizacja rytmu aktywności, który w ciagu tygodnia dopasowywał się do nowych warunków świetlnych, natomiast rytm dobowy H3K4me3 nadal utrzymywał swój szczyt w fazie jasnej. Wskazuje to na ostry wpływ swiatła na epigenom wattroby, prowadzacy do zakłócenia jego rytmu dobowego, którego nie mogły zresynchronizować nowe warunki świetlne. Przedłużenie eksperymentu na dalsze 8 tygodni, podczas których przesunięcie fazy świetlnej przedzielano tygodniowym powrotem do warunków kontrolnych, utrzymywało tę desynchronizację w wątrobie, czego nie obserwowano w epigenomie gruczołów podszczękowych. Wnioski tych doświadczeń wskazuja na desynchronizujace działanie przesunięcia fazy świetlnej na epigenom jednego $z$ zegarów peryferycznych (obecnego w watrobie), choć nie wskazuja mechanizmów, przy pomocy których dokonuje się transdukcja sygnału od reagujacego na światło głównego zegara obecnego w SCN. Moga to być drogi neurohormonalne, ale także wyłączenie pewnych mechanizmów pośredniczacych, do których można $z$ pewnością zaliczyć szyszynkę i produkowana w niej melatoninę. Ponieważ światło hamuje syntezę melatoniny, a rytm dobowy jest modyfikowany w zależności od fazy działania światła, to trudno jest rozdzielić te dwa mechanizmy (HARDELAND 2014).

Kolejna seria publikacji pochodzi $z$ jednego ośrodka badawczego (ZUBIDAT i współaut. 2015, ZuBIDAT i HAIM 2017) i dotyczy porównania u samic myszy $z$ przeszczepiona linia komórkowa 4T1 ludzkiego raka piersi skutków ekspozycji na nocne oświetlenie w różnych kombinacjach (barwa świtała, dodatkowe podawanie melatoniny). Oceniano m.in. aktywność szyszynki (poziom w moczu metabolitu melatoniny, czyli siarczanu, 6-SMT) oraz metylację DNA (DNAm) w samym guzie i w różnych narządach. Okazało się, że nocna ekspozycja na niebieskie światło LED stymulowała wzrost nowotworu i ułatwiała przerzutowanie. Towarzyszyło temu obniżenie zawartości 6-SMT w moczu oraz DNAm w guzie i watrobie, ale nie w płucach i śledzionie. Niskie wartości 6-SMT w moczu, świadczące o zmniejszonej syntezie melatoniny w szyszynce, były skorelowane ze wzrostem objętości nowotworu, w którym DNAm była niska. Natomiast podawanie melatoniny w wodzie pitnej odwracało skutki działania ALAN. Prowadzi to do wniosku, że zahamowana pod wpływem ALAN synteza melatoni- ny powoduje zmniejszona ogólną metylację DNA, ułatwiajaca proliferację komórek raka piersi, podczas gdy w warunkach normalnej nocnej syntezy melatoniny ma miejsce zwykła DNAm, wyciszająca rozwój komórek guza (ZUBIDAT i współaut. 2015). Pokrywa się to $z$ wynikami innych badaczy wskazujacymi, że melatonina wpływa modulująco na enzymatyczną metylację DNA (KORKMAZ i współaut. 2012).

Kolejne eksperymenty (ZUBIDAT i współaut. 2018) w takim samym układzie doświadczalnym, ale $z$ użyciem ALAN o różnej długości fali (500-595 nm), potwierdziły tłumienie syntezy melatoniny skorelowane negatywnie $z$ długością fali świetlnej. Najsilniejszy był wpływ światła o fali krótkiej (ok. $500 \mathrm{~nm})$ jednoczesny ze wzrostem guza, liczebnością przerzutów oraz hipometylacja DNA. Także w tym układzie doświadczalnym egzogenna melatonina odwracała niekorzystne efekty ALAN. Podobne ochronne działanie melatoniny uzyskiwali inni badacze (Cos i współaut. 2006) w przypadku nowotworu gruczołu piersiowego indukowanego u myszy chemicznie, kiedy zastosowanie ALAN także stymulowało wzrost guza, powodowało desynchronizację rytmu dobowego i zmniejszało przeżywalność badanych zwierząt (nie badano modyfikacji epigenetycznych). Przedstawione wyniki badań wskazuja na ścisłe powiazanie między skażeniem światłem a rozwojem raka piersi, którego nasilenie w braku nocnej syntezy melatoniny w szyszynce jest efektem zaburzeń globalnej metylacji DNA zarówno w tkance nowotworowej, jak i w innych narządach. Te niekorzystne efekty można cofnać podając egzogenną melatoninę (HAIM i współaut. 2019).

Porównywalną hipometylację DNA w trzustce wykazano także u samców szczurów poddawanych działaniu ALAN przez 3 tygodnie (2 x 30 min każdej nocy), towarzyszaca obniżonej syntezie melatoniny szyszynkowej, przy wzroście masy ciała, wydalania moczu i temperatury ciała, wraz $z$ zaburzeniami rytmu dobowego pobierania pokarmu i wody, oraz poziomu glukozy i insuliny w krwi (YoNis i współaut. 2019). Zmodyfikowana pod wpływem ALAN metylacja DNA ma szersze konsekwencje w postaci zaburzeń metabolizmu glukozy, lipogenezy, pobierania pokarmu i osmoregulacji, a także powoduje przesunięcia fazowe rytmów dobowych, zaś egzogenna melatonina jest w stanie odwracać te zmiany patologiczne.

\section{EGZOGENNA MELATONINA I SPOSOBY JEJ DOSTARCZANIA LUDZIOM}

W niektórych zaburzeniach snu oraz w przypadku podróży związanych z przekracza- 
niem stref czasowych stosuje się melatoninę jako suplement diety, wykorzystując jej funkcję chronobiotyczną (WICHNIAK i współaut. 2017, TSETI 2020). Dostępna w aptekach jako produkt OTC (ang. over the counter), czyli bez recepty, może mieć formę pastylek, granulek rozpuszczających się w ustach czy syropu, często także w połaczeniu $z$ witaminami rozpuszczalnymi $\mathrm{w}$ wodzie (np. B complex) czy minerałami (np. Zn), zwiększającymi efektywność jej działania. Biodostępność melatoniny jest niska, a za jej używaniem ze względów klinicznych przemawia bardzo niska (lub żadna) toksyczność i brak właściwości uzależniających. Podstawowym warunkiem skutecznego stosowania melatoniny jako suplementu diety jest przestrzeganie pory podawania, czyli ok. 2 godz. przed udaniem się na nocny spoczynek, natomiast dawka ma tu mniejsze znaczenie - nawet wysokie dawki przyjmowane bezpośrednio przed snem sa znacznie mniej efektywne pod względem skracania latencji snu niż dawki niższe, ale przyjmowane odpowiednio wcześniej. Efekty uboczne egzogennej melatoniny sa minimalne. Moga nimi być np. zaburzenia miesiaczkowania podczas stosowania bardzo wysokich dawek, wynikajace $z$ hamowania osi podwzgórzowo-przysadkowo-gonadowej, które znikaja po zaprzestaniu stosowania hormonu (TSETI 2020).

Ze względu na dużą zawartość melatoniny $\mathrm{w}$ niektórych produktach spożywczych prowadzone sa badania, których celem jest określenie ich wpływu na zdrowie konsumentów, zarówno osób zdrowych, jak i pacjentów $z$ różnymi zaburzeniami. Znaczne spożywanie roślin bogatych $\mathrm{w}$ melatoninę (zboża, owoce, warzywa) powoduje wzrost jej stężenia w krwi, skutkujące wzmożonym wydalaniem 6-SMT. Także spożywanie owoców tropikalnych (ananasów, bananów, pomarańczy, winogron), zarówno naturalnych, jak $\mathrm{i} \mathrm{w}$ formie soków, wiazało się $\mathrm{z}$ podwyższonym potencjałem antyoksydacyjnym krwi, skorelowanym dodatnio ze stężeniem melatoniny $\mathrm{w}$ surowicy (GOMES DOMINGOS i współaut. 2017). W przegladowej pracy MENGA i współaut. (2017) zestawiono wyniki licznych badań zawartości melatoniny w produktach spożywczych różnego pochodzenia, analizując zarazem jej przyswajalność i biodostępność, zwracając uwagę, że odżywianie się pokarmem bogatym $\mathrm{w}$ melatoninę nie musi być jednoznaczne $z$ większym jej dostarczaniem organizmowi. Spośród produktów spożywczych pochodzenia zwierzęcego najwięcej melatoniny zawieraja jaja i ryby, zaś w pokarmach roślinnych melatonina najobficiej występuje w orzechach, choć dobrym jej źródłem moga być także zboża oraz niektóre zioła, nasiona i kiełki warzyw.
W popularnych w Polsce zbożach: pszenicy, jęczmieniu i owsie zawartość melatoniny jest dość znaczna (odpowiednio 124,7 \pm 14,9 $\mathrm{ng} / \mathrm{g}$ świeżej masy; $82,3 \pm 6,0 \mathrm{ng} / \mathrm{g}$ i 90,6 $\pm 7,7 \mathrm{ng} / \mathrm{g})$, natomiast $\mathrm{w}$ najbardziej popularnych warzywach, czyli w ziemniakach i czerwonych burakach melatoniny nie ma prawie wcale. Bogatym jej źródłem sa za to bardzo lubiane grzyby, zwłaszcza rydze i borowiki. Wśród zbadanych 58 odmian kukurydzy zawartość melatoniny wahała sie od 0 do $2034 \mathrm{ng} / \mathrm{g}$ (średnio 96,5 ng/g), zaś w 25 odmianach ryżu analogiczne wartości wynosily od 0 do $264 \mathrm{ng} / \mathrm{g}$ (średnio $16 \mathrm{ng} / \mathrm{g}$ ), co wiąże się nie tylko $z$ genotypem rośliny, ale także $z$ klimatem i warunkami uprawy. Wykazano, że spożywanie pewnych pokarmów zawierających melatoninę istotnie podwyższa jej poziom w krwi; np. w doświadczeniu, w którym szczury karmiono pasza $\mathrm{z}$ dodatkiem orzechów włoskich $(3,5 \pm 1,0 \mathrm{ng} / \mathrm{g})$ stwierdzono wzrost zawartości melatoniny w krwi, wykazującej ponadto zwiększona aktywność antyoksydacyjną. Podobny efekty wykazano $\mathrm{u}$ ochotników w różnym wieku, pobierajacych przez 5 dni po dwie porcje $(200 \mathrm{ml})$ soku $\mathrm{Z}$ winogron, czemu towarzyszył podwyższony poziom 6-SMT w moczu, świadczacy o przyswajaniu egzogennego zwiazku zawartego $\mathrm{w}$ winogronach. Mimo niekiedy bardzo znacznych ilości melatoniny $\mathrm{w}$ produktach spożywczych, jej biodostępność jest raczej niewielka i zmienna (wyższa u kobiet - ok. $16 \%$, w porównaniu $z$ ok. $9 \%$ u mężczyzn), a okres półtrwania niewiele przekracza pół godziny. Liczne aktywności biologiczne melatoniny, oprócz dobroczynnego wpływu na zaburzenia rytmu snu i czuwania, przemawiaja za zwracaniem się ku jej pobieraniu z pokarmem, aczkolwiek wiele aspektów dostarczania egzogennej melatoniny pochodzenia pokarmowego wymaga jeszcze kontrolowanych badań doświadczalnych (Gomes Domingos i współaut. 2017, Meng i współaut. 2017).

\section{PODSUMOWANIE}

Przedstawione wyniki obserwacji populacji ludzkich i doświadczeń na zwierzętach laboratoryjnych jednoznacznie wykazują niekorzystne skutki zanieczyszczenia świetlnego, które można wobec tego traktować jako bardzo powszechny i niebezpieczny element skażenia naturalnego środowiska ludzi. Pierwsza "ofiara" tego skażenia jest nasz zegar endogenny, którego praca ulega desynchronizacji, czyli rozejściu się w czasie rytmów dobowych behawioru i większości procesów fizjologicznych $z$ warunkami środowiskowymi. Współczesny styl życia w krajach rozwiniętych eksponuje ludzi, zwłaszcza 
mieszkańców dużych miast, na obecność ALAN wynikajaca $z$ nieograniczonego używania oświetlenia elektrycznego, zwłaszcza zimnego światła LED ( $z$ dużą komponenta fal krótkich) o stosunkowo niskim zużyciu energii. Sytuację komplikuje życie w warunkach 24/7, co oznacza aktywność (zawodowa i/ lub towarzyska) przez cała dobę i każdego dnia w tygodniu, bez rozdzielenia czasu potrzebnego na wypoczynek $\mathrm{i}$ sen $\mathrm{w}$ godzinach nocnych. Nocna praca zmianowa, będaca naturalnym skutkiem rozwoju gospodarczego, jest kolejnym czynnikiem desynchronizujacym zegar biologiczny ludzi, podobnie jak loty transkontynentalne ( $z$ przekraczaniem stref czasowych) i powszechne użytkowanie wszechobecnych urządzeń emitujacych niebieskie światło LED. Takie światło działajace na ludzi w nocy wprawdzie wspomaga czujność i sprawność umysłowa w czasie ekspozycji, ale hamuje syntezę melatoniny szyszynkowej, naturalnego hormonu ciemności, przygotowującego narządy i procesy do nocnego wypoczynku i snu. Nieprzewidzianym skutkiem tak toczącego się życia pod dyktando postępu technologicznego sa coraz czesstsze, w skali globalnej, choroby tzw. cywilizacyjne, do których należą nowotwory, zaburzenia metaboliczne (otyłość, DMT2, zespół metaboliczny), depresja, co do których istnieja poważne podejrzenia, że rozwijaja się m.in. w wyniku zaburzenia prawidłowego funkcjonowania zegara biologicznego i desynchronizacji rytmów okołodobowych. Zaburzenia te wydaja się mieć u swego podłoża modyfikacje epigenetyczne, które, choć dziedziczne, na szczęście sa odwracalne. Dlatego dalszy rozwój technologiczny powinien się koncentrować na ograniczaniu skażenia światłem, wprowadzaniu urządzeń jak najmniej zakłócajacych funkcjonowanie zegara i syntezę melatoniny szyszynkowej oraz ograniczanie pracy zmianowej i życia w trybie $24 / 7 / 365$. W pośpiesznym życiu w zglobalizowanym świecie powinien zawsze znaleźć się czas na sen we właściwych ilościach, warunkach i w porach naturalnie do tego przeznaczonych.

\section{Streszczenie}

Mieszkańcy Ziemi zaadaptowali swoją fizjologię i behawior do 24-godzinnej doby $z$ regularnym następstwem dnia i nocy dzięki działaniu endogennego mechanizmu molekularnego zwanego zegarem biologicznym. Zegar biologiczny jest synchronizowany $z$ otoczeniem dzięki temu, że odbiera sygnały środowiskowe zwane dawcami czasu, z których najważniejszym jest światło. Kiedy jednak światło pojawia się $\mathrm{w}$ nieodpowiednim momencie, np. sztuczne światło w nocy (ALAN), jego wpływ może być szkodliwy dla organizmu, powodujacc zakłócenie naturalnego cyklu snu i czuwania, prowadząc także do licznych zaburzeń metabolizmu i behawioru. Informacja o warunkach świetlnych otoczenia przekazywana jest do całego organizmu za pośrednictwem nocnej syntezy i uwalniania do krwi szyszynkowego neurohormonu melatoniny. Dlatego obecność światła w niewłaściwym czasie i ilości powoduje hamowanie syntezy melatoniny i desynchronizację zegara biologicznego. Coraz więcej badań potwierdza pogląd, że zaburzenie syntezy melatoniny pod wpływem ALAN prowadzi do modyfikacji epigenetycznych i nieprawidłowej transkrypcji pewnych genów, a to skutkuje zwiększoną częstością wielu chorób, np. raka czy zespołu metabolicznego.

\section{PIŚMIENNICTWO}

ACHERMANN P., TAROKH L., 2014. Human sleep and its regulation. Kosmos 63, 173-180.

Ahmad S. F., Shanaz S., Kumar A., DaR A. H., MOHMAD A., BHUSHAN B. 2019. Crosstalk of epigenetics with biological rhythmicity in animal kingdom. Biol. Rhythm Res., doi: 10.1080/09291016.2019.1607218.

AuBe M., RoBY J., KocIFAJ M., 2013. Evaluating potential spectral impacts of various artificial lights on melatonin suppression, photosynthesis, and star visibility. Plos ONE 8, e67798.

BELl-PEDERSEN D., CASSONE V. M., EARNEST D. J., Golden S. S., Hardin P. E., ThOMAS T. L., ZORAN M. J., 2005. Circadian rhythms from multiple oscillators: lessons from diverse organisms. Nature Rev. Drug Disc., doi: 10.1038/ nrg1633.

Berson D. M., DunN F., TAKaO M., 2002. Photo-transduction by retinal ganglion cells that set the circadian clock. Science 295, 1070-1073.

BONMATI-CARRION M. A., ARGUElles-PRIETO R., MARTINEZ-MADRID M.-J., REITER R., HARDELAND R., ROL M. A., MADRID J. A., 2014. Protecting the melatonin rhythm through circadian healthy light exposure. Int. J. Mol. Sci.15, 2344823500 .

BRINGMANN H., 2019. Genetic sleep deprivation. EMBO Rep. 20, doi: 10.15252/ embr.201846807.

Chang A.-M., Aeschbach D., Duffy J. F., CZEISLER C. A., 2015. Evening use of light-emitting eReaders negatively affects sleep, circadian timing, and next-morning alertness, Proc. Natl. Acad. Sci USA 112, 1232-1237.

Cos S., Mediavilla D., Martínez-Campa C., GonZÁlEZ A., AlONSO-GONZÁlEZ C., SÁNCHEZ-BARCELÓ E. J., 2006. Exposure to light-at-night increases the growth of DMBA-induced mammary adenocarcinomas in rats. Cancer Lett. $235,266-271$

Dubocovich M., MARKowska M., 2005. Functional MT1 and MT2 melatonin receptors in mammals. Endocrine 27, 101-110.

Fabrizio P., Garvis S., Palladino F., 2019. Histone methylation and memory of environmental stress. Cells 8, doi: 10.3390/cells8040339.

Foster R. G., KREITZMAN L., 2014. The rhythms of life: what your body clock means to you! Exp. Physiol. 99, 599-606.

FroY O., 2011. The circadian clock and metabolism. Clin. Sci. 120, 65-72.

GANGWISCH J. E., 2014. Invited commentary: Nighttime light exposure as a risk factor for obesity through disruption of circadian and circannual rhythms. Am. J. Epidemiol. 180, 251-253.

Gaston K. J., Sian G., Bennie J., Hopkins J., 2015. Benefits and costs of artificial nighttime lighting of the environment. Environ. Rev. 23, 14-23. 
Giebultowicz J. M., 2018. Mechanism of circa dian clock. The 2017 Nobel Prize in physiology or medicine. Kosmos 67, 245-249.

Gillman A. G., Rebec G. V., Pecoraro N. C., KoSOBUD A. E. K., 2019. Circadian entrainment by food and drugs of abuse. Beh. Proc. 165, 23-38.

GLAVAŠKI M., STANKOV K., 2019. Epigenetics in disease. Etiopathogenesis. Genetika 51, 957994.

GobBi G., ComaI S., 2019. Differential function of melatonin $M T$ and $M T$ receptors in REM and NREM sleep. Front. Endocrinol., doi: 10.3389/fendo.2019.0087.

GOMES DOMINGOS A.L., HERMSDORFF H.H.M. BRESSAN J., 2017, Melatonin intake and potential chronobiological effects on human he alth, Crit. Rev. Food Sci. Nutr., doi:10.1080/ 10408398.2017.1360837.

GrygoryeV D., Rountree M.R., RWATAMBuga F., OHlRich A., Kukino A., Butler M. P., Allen C.N., TURKER M.S., 2018. Rapid response and slow recovery of the H3K4me3 epigenomic marker in the liver after light-mediated phase advances of the circadian clock. J. Biol. Rhythms. 33, 363-375.

HARDELAND R., 2014. Melatonin, noncoding RNAs, messenger RNA stability and epigenetics Evidence, hints, gaps and perspectives. Int. J. Mol. Sci. 15, 18221-18252.

HARDELAND R., 2017. Future demands concerning the epigenetic relevance of melatonin and the circadian system in gerontology. J. Geriatr. Med. Gerontol. 3, doi: 1023937/2469$5858 / 1510036$.

Hashimoto H., Vertino P. M., Cheng X., 2010. Molecular coupling of DNA methylation and histone methylation. Epigenomics 2, 657-669.

IARC 2010, Monographs on the evaluation of carci nogenic risks to humans. Painting, firefighting and shiftwork. International Agency for Research on Cancer. Publikacja Światowej Organizacji Zdrowia (WHO) 98, 563-601.

JABBARI K., BERNARDI G., 2004. Cytosine methylation and $C p G, T p G(C p A)$ and $T p A$ frequencies. Gene 333,143-149.

KoŁOMAŃSKI S., 2014. Zanieczyszczenie światłem $i$ ciemność. Prace Studia Geogr. 53, 29-46.

KORKMAZ A., Rosales-CORRAL S., REITER R. J., 2012. Gene regulation by melatonin linked to epigenetic phenomena. Gene, doi: 10.1016/j. gene.2012.04040.

KNUTSON K. L., VAN CAUTER E., 2008. Associations between sleep loss and increased risk of obesity and diabetes. Ann. NY Acad. Sci. $1129,287-304$.

MCFADDEN E., Jones M. E., SChOEMAKeR M. J., ASHWORTH A., SWERDLOW A. J., 2014. The relationship between obesity and exposure to light at night: cross-sectional analyses of over 100,00 women in the Breakthrough Generations Study. Am. J. Epidemiol. 180, 245-250.

Meng X., LI Y., LI S., ZHOU Y., GAN R.-Y., XU D.-P., LI H.-B., 2017. Dietary sources and bioactivities of melatonin, Nutrients 9, doi: $10.3390 /$ nu9040367.

REITER R. J., 1993. The melatonin rhythm: both a clock and a calendar. Experientia 49, 654664.

REUTRAKUL S., VAN CAUTER E., 2014. Interactions between sleep, circadian function, and glucose metabolism: implications for risk and severity of diabetes. Ann. NY Acad. Sci. 1311, 151173.

RoenneBerg T., Pilz L. K., Zerbini G., WinNeBeck E. C., 2019. Chronotype and social jetlag: A
(Self-) critical review. Biology 8, doi: 10.3390/ biology8030054.

RoGE-WIŚNIEWSKA M., 2014. Światło - dobrodziejstwo czy problem? Prace Studia Geogr. 53, $15-28$.

SKWAREO-SOŃTA K., 2014. Melatonina. Hormon snu czy hormon ciemności? Kosmos 63, 223-231.

SKWARŁO-SONTA K., MAJEWSKI P., 2010. Melatonina, wielofunkcyjna czasteczka sygnałowa $w$ organizmie ssaka: miejsca biosyntezy, funkcje, mechanizmy działania. Folia Med. Lodz 37/1, $1-41$.

TseTI I. K., 2020. Melatonin as a food supplement for sleep disorders. doi: http:/dx.doi. org/10.5772/intechopen.91410.

WESOEOWSKI M., GRONKOWSKI P., 2019. Symulacja gwałtownego wzrostu jasności komet $w$ aspekcie zanieczyszczenia nieba sztucznym światłem. [W:] Zanieczyszczenie światłem. Zródła, obserwacje, skutki. A. Z. KOTARBA (red.). Centrum Badań Kosmicznych PAN, Warszawa, 185-197.

WICHNIAK A., JANKOWSKI K. S., SKALSKI M., SKWARŁO-SOŃTA K,. ZAWILSKA J. B., ŻAROWSKI M., PORADOWSKA E., JERNAJCZYK W., 2017. Treatment quidelines for circadian rhythm sleep-wake disorders of the Polish Sleep Research Society and the Section of Biological Psychiatry of the Polish Psychiatric Association. Part I. Physiology, assessment and therapeutic methods. Psychiatr. Pol. 51, 793-814.

WOJCIECHOWSKA R., 2019. Czy oświetlenie nocne może zaburzać funkcjonowanie roślin? [W:] Zanieczyszczenie światłem. Źródła, obserwacje, skutki. A. Z. KOTARBA (red.). Centrum Badań Kosmicznych PAN, Warszawa, 39-54.

WOJCIECHOWSKA A., WIŚNIEWSKA A., BARCIKOWSK A., 2014. Zanieczyszczenie świattem - ekologiczny problem współczesnego miasta. Prace Studia Geogr. 53, 109-128.

Wood B., ReA M. S., Plitnick B., Figueiro M.G., 2012. Light level and duration of exposure determine the impact of self-luminous tablets on melatonin suppression. Appl. Ergonomics 44, 1-4.

WRIGHT K. P. JR, MCHILl A.W., BIRKS B. R., GRIFFIN B. R., REUSTERHOLZ T., CHINOY E. D., 2013. Entrainment of the human circadian clock to the natural light-dark cycle. Curr. Biol. 23, 1554-1558.

Yonis M., HAIM A., ZuBIDAT A. E., 2019. Altered metabolic and hormonal responses in male rats exposed to acute bright light-at-night associated with global DNA hypo-methylation. J. Photochem. Photobiol. B Biol. 194, 107-118.

ZHANG X., Ho S.-M, 2011. Epigenetics meets en docrinology. J. Mol. Endocrinol. 46, R11-R32.

ZHANG C., YANG L., LIU S., MA S., WANG Y., CAI Z., DU H., Li R., Kang L., Su M., Zhang J., LIU Z., ZHANG B., 2020. Survey of insomnia nad related social psychological factors among medical staff involved in the 2019 novel coronavirus disease outbreak. Front. Psychiatry 11, doi: 10.3389 /fpsyt.2020.00306.

Zubidat A.E., Haim A., 2017. Artificial light-at-night - a novel lifestyle risk factor for metabolic disorder and cancer morbidity. J. Basic Clin. Physiol. Pharmacol. 28, 295-313.

ZUBIDAT A. E., FARES B., FARES F., HAIM A., 2015. Melatonin functioning through DNA methylation to constricts breast cancer growth accelerated by blue LED light-at-night in $4 T 1$ tumor-bearing mice. J. Cancer Biol. Therap. 1-2, 57-73.

ZubidaT A.E., FARES B., FARES F., Haim A., 2018. Artificial light at night of different spectra com- 
positions differentially affects tumor growth in mice: interaction with melatonin and epigenetic pathways. Cancer Control 25, 1-15.

ZYCH M., RYNIEWICZ J., 2019. Nocna zmiana: $w$ jaki sposób zanieczyszczenie światłem wpływa na mutualistyczne relacje roślin $i$ ich zapylaczy? [W:] Zanieczyszczenie światłem. Źródła, obserwacje, skutki. A. Z. KOTARBA (red.). Centrum Badań Kosmicznych PAN, Warszawa, 55-66.

KOSMOS Vol. 69, 3, 447-459, 2020

\section{KRYSTYNA SKWARŁO-SOŃTA}

Department of Animal Physiology, Faculty of Biology, University of Warsaw, 1 Miecznikowa Str., 02-096 Warszawa, Poland, E-mail: kss25@biol.uw.edu.pl

\section{LIGHT AT NIGHT - DOES IT IMPAIR QUALITY OF SLEEP ONLY? MEDIATION OF EPIGENETICS IN THE EFFECT OF LIGTH POLLUTION ON HUMAN ORGANISM}

\section{Summary}

The inhabitants of the Earth have adapted their physiology and behavior to the 24-hour day with regular day and night sequences thanks to the action of an endogenous molecular mechanism called the biological clock. The biological clock is synchronized with the environment because it picks up environmental signals called time givers, the most important of which is light. However, when light arrives at the wrong time, such as artificial light at night (ALAN), its effects can be detrimental to the body, disrupting the natural sleep-wake cycle and leading to numerous disorders of metabolism and behavior. Information about the light conditions of the environment is transmitted to the whole organism through night-time synthesis and release of the pineal neurohormone, melatonin, into the blood. Therefore, the presence of light at the wrong time and quantity causes the inhibition of melatonin synthesis and the desynchronization of the biological clock. More and more studies confirm the view that the disturbance of melatonin synthesis by ALAN leads to epigenetic modifications and incorrect transcription of certain genes, and this results in an increased incidence of many diseases, e.g. cancer or metabolic syndrome.

Key words: circadian rhythms, light pollution, ALAN, sleep and awakening, melatonin, epigenetics 